\title{
Review and integrative taxonomy of the genus Prosopistoma Latreille, 1833 (Ephemeroptera, Prosopistomatidae) in Thailand, with description of a new species
}

\author{
Boonsatien Boonsoong', Michel Sartori ${ }^{2,3}$ \\ I Animal Systematics and Ecology Speciality Research Unit (ASESRU), Department of Zoology, Faculty of \\ Science, Kasetsart University, Bangkok 10900, Thailand 2 Museum of Zoology, Palais de Rumine, Place Ri- \\ ponne 6, CH-1005 Lausanne, Switzerland 3 Department of Ecology and Evolution, Lausanne University, \\ CH-1015 Lausanne, Switzerland \\ Corresponding author: Boonsatien Boonsoong (fscibtb@ku.ac.th) \\ Academic editor: B. Price | Received 14 December 2018 | Accepted 24 January 2019 | Published 27 February 2019 \\ http://zoobank.org/4F785350-7E19-4BED-92B0-5271E3165879 \\ Citation: Boonsoong B, Sartori M (2019) Review and integrative taxonomy of the genus Prosopistoma Latreille, 1833 \\ (Ephemeroptera, Prosopistomatidae) in Thailand, with description of a new species. ZooKeys 825: 123-144. https:// \\ doi.org/10.3897/zookeys.825.32443
}

\begin{abstract}
Three species of the genus Prosopistoma Latreille, 1833 (Prosopistomatidae) are currently reported from Thailand. A new species, Prosopistoma carinatum sp. n., is described here based on specimens from western and southern Thailand. The new species can be easily distinguished from the other members of Prosopistoma by the following combination of characteristics: (i) the presence of two ridged longitudinal lines on each side of its carapace, (ii) antenna 7-segmented, (iii) a strongly convex carapace and (iv) nine pectinate setae on the ventral margin of the fore tibiae. A comparison between the key characteristics of $P$. carinatum sp. n. and the known Thai species is provided. Results of analysis of the mitochondrial cytochrome oxidase I (COI) gene (658 bp) of three species, as well as the distribution of the Thai species, are also discussed.
\end{abstract}

\section{Keywords}

Prosopistoma carinatum, Prosopistoma annamense, Prosopistoma sinense, COI, mayfly

Copyright Boonsatien Boonsoong, Michel Sartori. This is an open access article distributed under the terms of the Creative Commons Attribution License (CC BY 4.0), which permits unrestricted use, distribution, and reproduction in any medium, provided the original author and source are credited. 


\section{Introduction}

Prosopistomatidae (Ephemeroptera) is a monogeneric family, represented by the genus Prosopistoma, which was originally established by Latreille (1833). Of the 27 species described to date, 16 species have been described from the Oriental region (Lieftinck 1932, Peters 1967, Soldán and Braasch 1984, Tong and Dudgeon 2000, Sartori and Gattolliat 2003, Zhou and Zheng 2004, Barber-James et al. 2008, Barber-James 2009, Shi and Tong 2013; Balachandran et al. 2016, Roopa et al. 2017). An updated key to the known species of this realm was provided by Shi and Tong (2013).

In Thailand, only the larvae of Prosopistoma annamense Soldán \& Braasch, 1984, P. sinense Tong \& Dudgeon, 2000, and P. wouterae Lieftinck, 1932 are known (Parnrong et al. 2002, Tungpairojwong and Boonsoong 2011). In the present study, we describe a new species of Prosopistoma based on specimens from western and southern Thailand. In addition, a distribution map of the genus in Thailand and mitochondrial COI sequence data are provided.

\section{Materials and methods}

The prosopistomatid mayfly larvae were collected from streams and rivers in northern, north-eastern, eastern, central, western, and southern Thailand from 2013 to 2018. Measurements (given in $\mathrm{mm}$ ) and photographs were taken using a Visionary LK System (Dun, Incorporated, USA). All drawings were made with the aid of a camera lucida attached to a compound microscope. For Scanning electron microscopy (SEM), specimens (head, carapace, sternal plate, foreleg) were dried in a Critical Point Drier (CPD7501) and coated with gold (10 nm, Sputter Coater SC7620). SEM photographs were observed by a FEI Quanta 450 SEM. Final plates were prepared with Adobe Photoshop CC 2017. The material is deposited in the collection of the Zoological Museum at Kasetsart University in Bangkok, Thailand (ZMKU) and at the Museum of Zoology in Lausanne, Switzerland (MZL). The distribution map was generated via the Simple Mapper website (http://www.simplemappr.net) using GPS coordinates.

The collected specimens were fixed in absolute ethanol and preserved under refrigeration for description and DNA extraction. Details of the specimens from the three species used for the DNA experiment are shown in Table 1. Total DNA extraction was performed using a genomic DNA purification kit (NucleoSpin, Macherey-Nagel, Germany) following the manufacturer's protocol. A fragment of the mitochondrial gene cytochrome oxidase I (COI) gene was amplified (658 bp) using the primers LCO1490 (5'-GGT CAA ATC ATA AAG ATA TTG G-3') and HCO2198 (5'-TAA ACT TCA GGG TGA CCA AAA AAT CA-3'), designed by Folmer et al. (1994). Polymerase chain reaction (PCR) conditions were as follows: a $50 \mu \mathrm{l}$ final reaction volume containing $25 \mu \mathrm{l}$ of PCR Master mix solution, $1 \mu \mathrm{l}(10 \mu \mathrm{m})$ of each primer, $2 \mu \mathrm{l}$ of total DNA and $21 \mu \mathrm{l}$ of nuclease free sterile water. PCR was performed as follows: 5 minutes at $94{ }^{\circ} \mathrm{C}$, then 30 seconds at $94^{\circ} \mathrm{C}, 30$ seconds at $48{ }^{\circ} \mathrm{C}$, and 60 seconds at $72{ }^{\circ} \mathrm{C}(40$ cycles), and a final elongation step at $72^{\circ} \mathrm{C}$ for 10 minutes (Gattolliat et al. 2015). Pu- 
Table I. List of the sequenced specimens.

\begin{tabular}{lccccc}
\hline \multicolumn{1}{c}{ Species } & Code & Collection locality & Collector & Date & $\begin{array}{c}\text { GenBank accession } \\
\text { number }\end{array}$ \\
\hline P. annamense & PA-01-KN & Kanchanaburi & B. Boonsoong & 15 Oct 2015 & MK285321 \\
& PA-12-RT & Ratchaburi & B. Boonsoong & 13 Feb 2016 & MK285322 \\
& PA-13-LE & Loei & B. Boonsoong & 19 Mar 2016 & MK285323 \\
& PA-17-NN & Nakhon Nayok & B. Boonsoong & 25 Feb 2017 & MK285324 \\
& PA-18-CT & Chantaburi & B. Boonsoong & 5 Jul 2018 & MK285325 \\
P. carinatum sp. n. & PC-01-KN & Kanchanaburi & B. Boonsoong & 26 Apr 2014 & MK285326 \\
& PC-02-KN & Kanchanaburi & B. Boonsoong & 26 Apr 2014 & MK285327 \\
P. sinense & PS-01-KN & Kanchanaburi & B. Boonsoong & 20 Feb 2016 & MK285328 \\
& PS-02-KN & Kanchanaburi & B. Boonsoong & 20 Feb 2016 & MK285329 \\
& PS-03-CM & Chaing Mai & B. Boonsoong & 11 Mar 2017 & MK285330 \\
\hline
\end{tabular}

rification and sequencing were conducted by Macrogen, Inc. (South Korea). Sequence alignment and editing were performed using ClustalW. The best-fit evolution model obtained was T92 (Tamura 3-parameter) + G. Phylogenetic trees based on maximum likelihood (ML) were performed with MEGA 7 using the likelihood-ratchet method with 1,000 bootstrap replicates. Pairwise (uncorrected-p) sequence distances were also calculated using MEGA 7 (Kumar et al. 2016). Nucleotide sequences obtained in this study have been deposited in the GenBank database (MK285321-MK285330).
Abbreviations
C central;
N northern;
W western.
m meter;
NE north-eastern;

\section{Taxonomy}

Family Prosopistomatidae Lameere, 1917

Genus Prosopistoma Latreille, 1833

\section{Prosopistoma annamense Soldán \& Braasch, 1984}

Figures 1A, 1B, 2A, 2B, 2C, 2D, 3A, 3B, 3C, 12A, 12B, 12C, 14

Prosopistoma annamense Soldán \& Braasch, 1984: 370-376, figs. 2, 4, 6, 8, 13, 14. (orig.); Barber-James, 2009: 153-154, Table 2 (morph. matrix); Tungpairojwong \& Boonsoong, 2011: 67-68; Shi \& Tong, 2013: 95 (key).

Material examined. THAILAND; 1 larva, Chanthaburi province, Klong Kla Seu Yai, Khao Kitchakut, 1252'35.94"N, 10205'48.3"E, 40 m, 7.II.2013, 2 larvae, same place, 6.VII.2018, B Boonsoong leg. (ZMKU); 1 larva, Nakhon Nayok prov- 

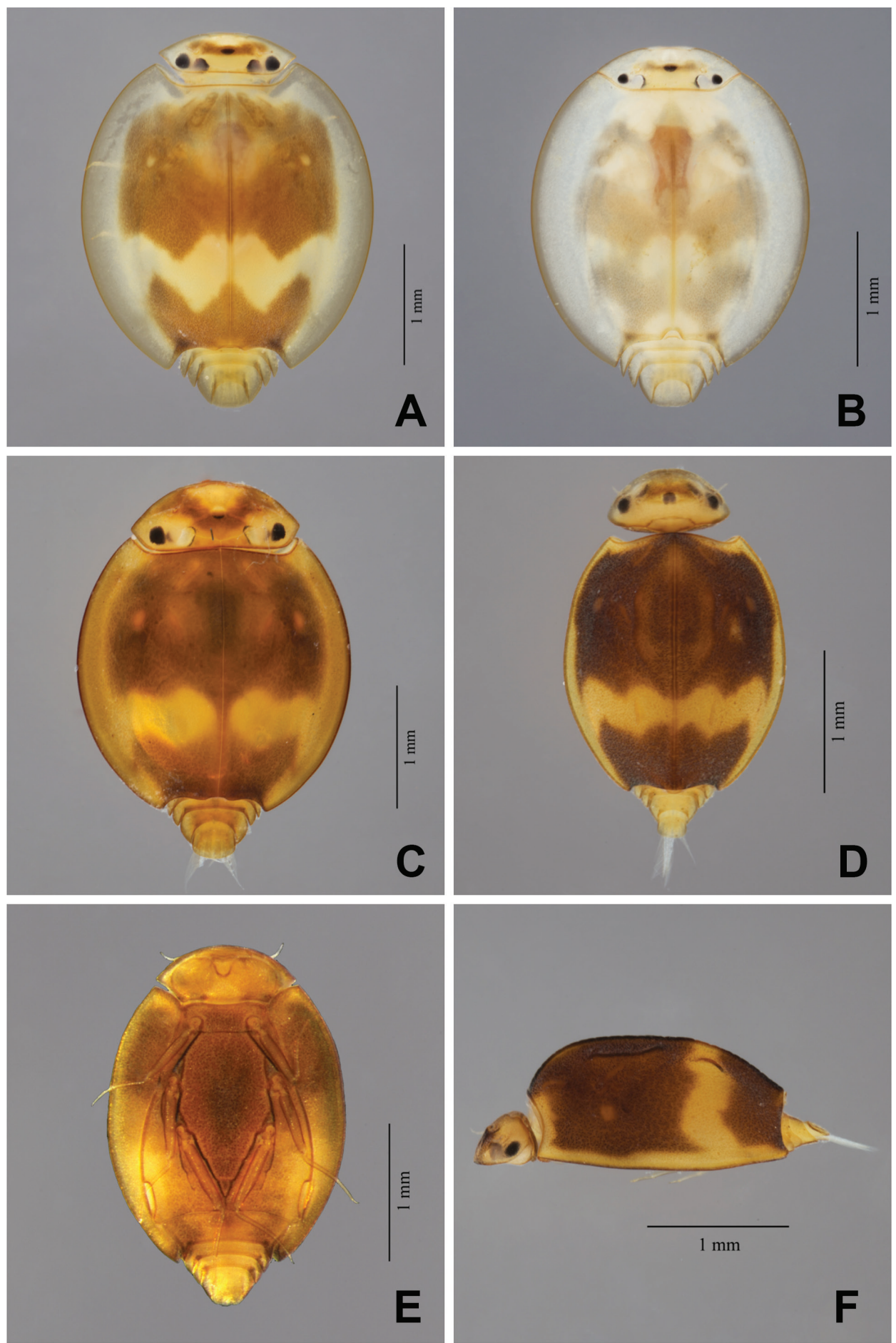

Figure I. Prosopistoma spp. whole larvae: A-B P. annamense, specimens from stream $(\mathbf{A})$ and river $(\mathbf{B})$; C $P$. sinense $\mathbf{D}-\mathbf{F}$ P. carinatum sp. n. $\mathbf{D}$ dorsal view $\mathbf{E}$ ventral view $\mathbf{F}$ lateral view. 
Table 2. Uncorrected pairwise genetic distances (COI) between selected prosopistomatid and baetiscid species, using the Kimura 2-parameter.

\begin{tabular}{lcccc}
\hline & B. laurentina & P. annamense & P. carinatum sp. n. & P. sinense \\
\hline B. laurentina & - & - & - & - \\
P. annamense & 0.32 & - & - & - \\
P. carinatum sp. n. & 0.23 & 0.31 & - & - \\
P. sinense & 0.34 & 0.33 & 0.35 & - \\
\hline
\end{tabular}

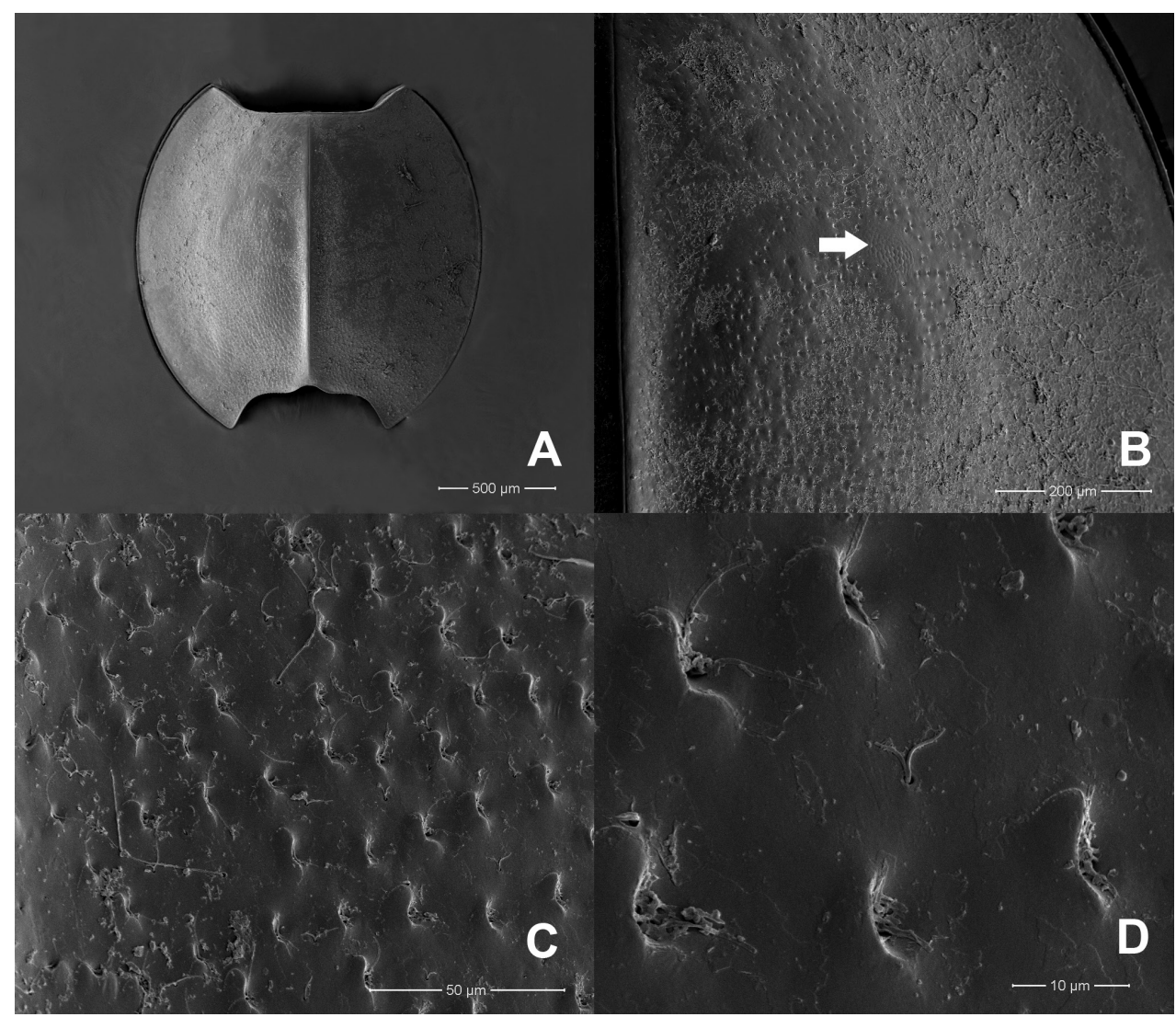

Figure 2. Prosopistoma annamense: A SEMs of notal shield, dorsal view B pale-coloured areas on carapace (arrow) C scale-like structures $\mathbf{D}$ closer view showing details of scale-like structures.

ince, Wang Ta Krai, 14²19'35.9"N, 101¹8'05.9"E, 65 m, 24.III.2013, B Boonsoong leg. (ZMKU); 5 larvae, Kanchanaburi province, Thong Pha Phum, Phu Iyara Resort, 14³7'34.4"N, 98³4'17.0"E, 207 m, 6.IV.2013, B Boonsoong leg. (ZMKU), 1 larva same data (MZL, GBIFCH00657966); 1 larva, Ban Pra Chum Mai, 14³5'01.4"N, 98³4'54.3"E, 233 m, 26.IV.2014, B Boonsoong leg. (ZMKU); 5 larvae, Kanchanaburi

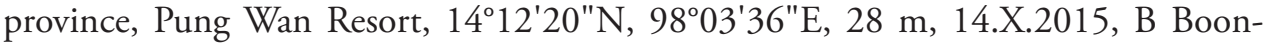


soong leg. (ZMKU), 1 larva same data (MZL, GBIFCH00657965); 3 larvae, Loei

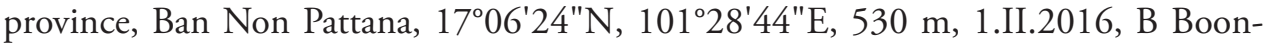
soong leg. (ZMKU); 3 larvae, Ratchaburi province, Kang Som Maew, Suan Phueng, 1324'27.6"N, 99¹6'51.3"E, 206 m, 13.II.2016, B Boonsoong leg. (ZMKU); 6 larvae, Loei province, Ban Non Pattana, 1706'24"N, 101²8'44"E, 530 m, 19.III.2016, B Boonsoong leg. (ZMKU); 2 larvae, Nakhon Nayok province, Wang Ta Krai, $14^{\circ} 20^{\prime} 9.42^{\prime \prime N}, 101^{\circ} 18^{\prime} 22.5^{\prime \prime E}, 67 \mathrm{~m}, 25 . I I .2017$, B Boonsoong leg. (ZMKU); 2 larvae, Chanthaburi province, Klong Sa Tor Bon, 1243'12.42"N, 102²3'19.26"E, 115 m, 5.VII.2018, B Boonsoong leg. (ZMKU).

Diagnosis. The larvae of $P$. annamense can be distinguished from those of other Oriental congeners by (i) apex of the inner margin of the fore tibiae, with 4-6 serrated pectinate spines (Fig. 3B), (ii) three long, finely serrated bristles at the base of the inner incisor, on both right and left mandible, (iii) segment III of the maxillary palp slightly shorter than $1 / 3$ the length of segment II and (iv) posterolateral spines at segments VII and VII parallel to or bent outwards from the body axis (Fig. 1A, B).

Distribution. Loei province (NE), Nakhon Nayok province (C), Chanthaburi province (E), Kanchanaburi province (W), Ratchaburi province (W).

Remarks. The larvae of $P$. annamense were originally described by Soldán and Braasch (1984) and collected from Vietnam (Thuan Hai province). They are widely distributed in southern and central Vietnam. Tungpairojwong and Boonsoong (2011) reported this species in middle and moderately disturbed streams in Loei province (NE), Chaiyaphum province (NE) and Kanchanaburi province (W). In this study, we found this species in several provinces, and it seems to have a wide distribution in Thailand. Surprisingly, we found larvae on the banks of the Khwae Noi River (Kanchanaburi province) (Fig. 12C). This is the first report of Prosopistoma larvae in large rivers in Thailand, and the larvae collected from large rivers are paler than those larvae from streams (Fig. 1B).

\section{Prosopistoma sinense Tong \& Dudgeon, 2000}

Figures $1 \mathrm{C}, 4 \mathrm{~A}, 4 \mathrm{~B}, 4 \mathrm{C}, 4 \mathrm{D}, 5 \mathrm{~A}, 5 \mathrm{~B}, 5 \mathrm{C}, 12 \mathrm{D}, 14$

Prosopistoma sinense Tong \& Dudgeon, 2000: 122-128, figs. 1-14. (orig.); BarberJames, 2009: 153-154, Table 2 (morph. matrix); Tungpairojwong \& Boonsoong, 2011: 68; Shi \& Tong, 2013: 95 (key).

Material examined. THAILAND; 2 larvae, Kanchanaburi province, Thong Pha Phum, Pussaduklang Ranger Station, 14³3'13"N, 98³4'17"E, 317 m, 20.II.2016, B Boonsoong leg. (ZMKU); 2 larvae, Kanchanaburi province, Thong Pha Phum, Pak Kok stream, 14939'32.1"N, 98³1'59.2"E, 161 m, 20.II.2016, B Boonsoong leg. (ZMKU), 1 larva same data (MZL, GBIFCH00657969); 4 larvae, Chiang Mai province, Chiang Dao, Mae Na, 19¹9'13.08"N, 9853'25.98"E, 742 m, 11.III.2017, B Boonsoong leg. (ZMKU). 


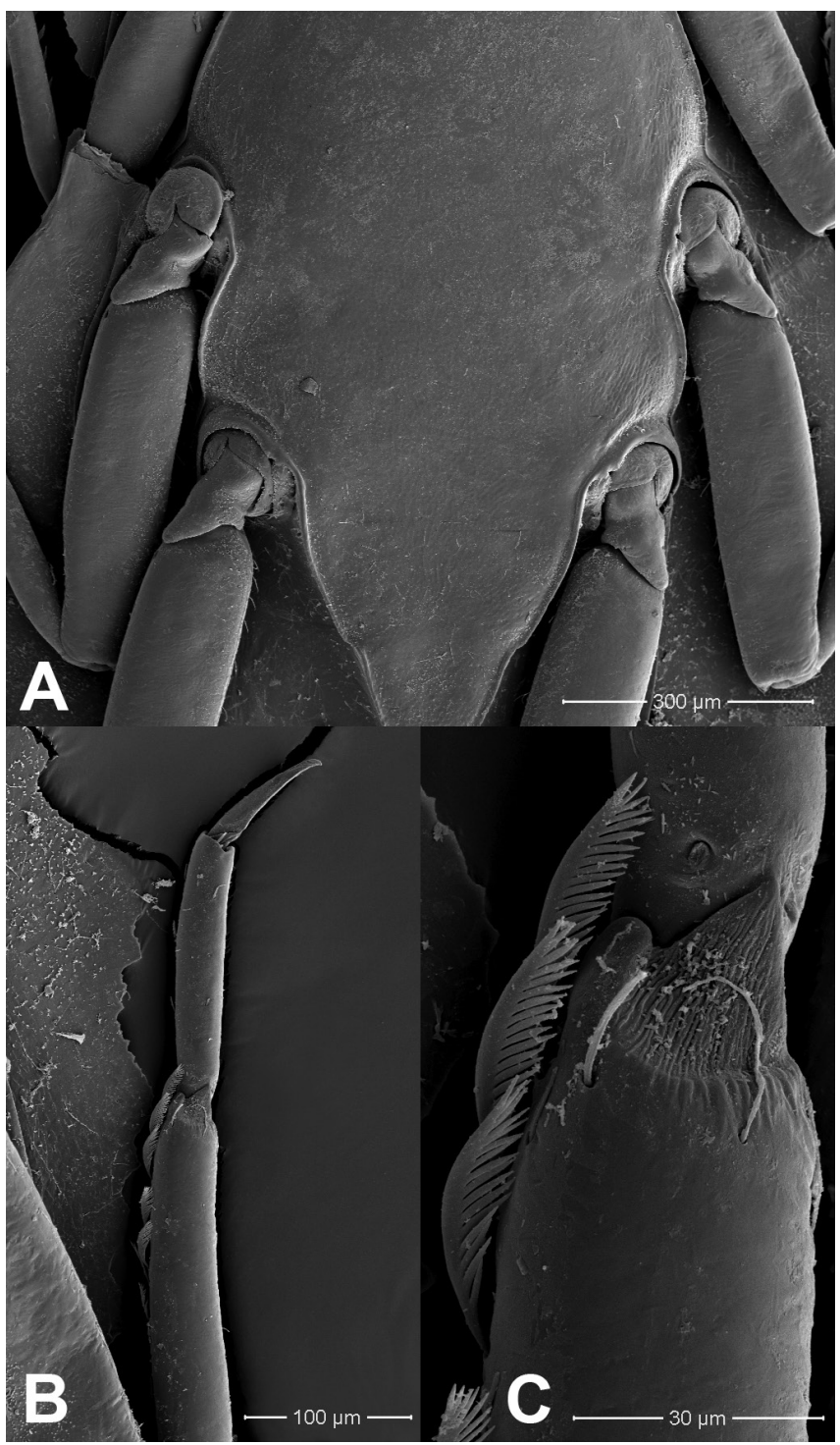

Figure 3. Prosopistoma annamense: A SEMs of sternal plate $\mathbf{B}$ ventral margin of fore tibia $\mathbf{C}$ pectinate setae.

Diagnosis. The larvae of Prosopisoma sinense can be distinguished from those of other congeners by (i) antennae with 4-5 segments, (ii) antenna segment III much longer than the combined length of segments IV-V (iii) and apex of the ventral margin of the fore-tibia with 6-8 serrated spines (Fig. 4B) (Shi and Tong 2013).

Distribution. Kanchanaburi province (W), Chiang Mai province (N).

Remarks. The larvae of $P$. sinense were originally described by Tong and Dudgeon (2000) and collected from China (Guangdong, Hongkong). In Thailand, Tungpairojwong and Boonsoong (2011) reported this species from a slightly disturbed stream 


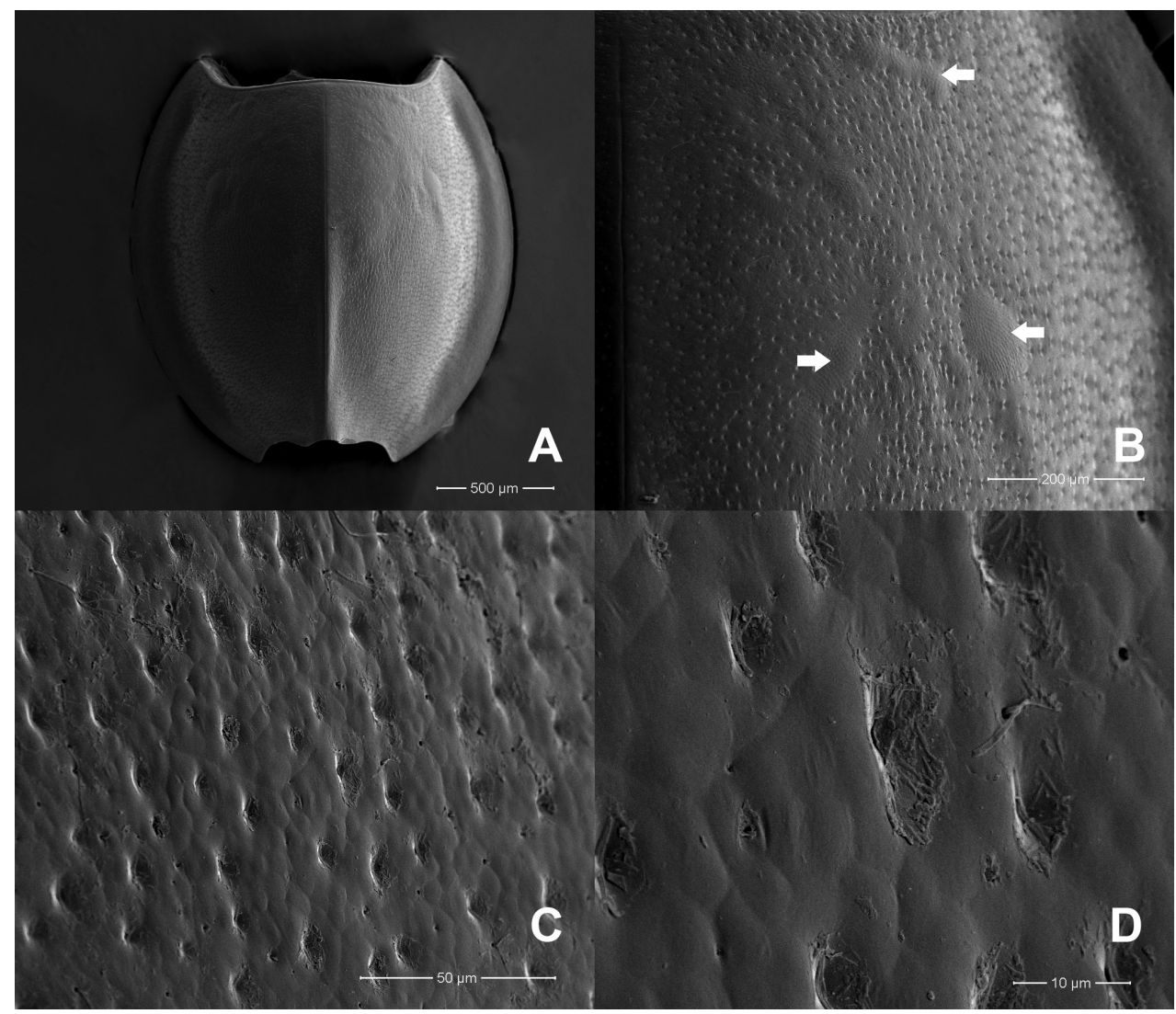

Figure 4. Prosopistoma sinense: A SEMs of notal shield, dorsal view B pale-coloured areas on carapace (arrow) $\mathbf{C}$ scale-like structures $\mathbf{D}$ closer view showing details of scale-like structures.

in Kanchanaburi province. In this study, we found the larvae in the same habitat (Fig. 12D) and streams as previous studies. In addition, we found this species at a slightly disturbed stream in Chiang Dao, Chiang Mai province $(\mathrm{N})$.

\section{Prosopistoma wouterae Lieftinck, 1932}

Figure 14

Prosopistoma wouterae Lieftinck, 1932: 44-55, pls 1-2. (orig.); Lafon, 1952: 433 (table); Peters, 1967: 211-213, figs 2, 8, 10, 16, 26 (redescription); Soldán \& Braasch, 1984; 374-375 (key); Barber-James, 2009: 153-154, Table 2 (morph. matrix); Shi \& Tong, 2013: 95 (key).

Material examined. None. 


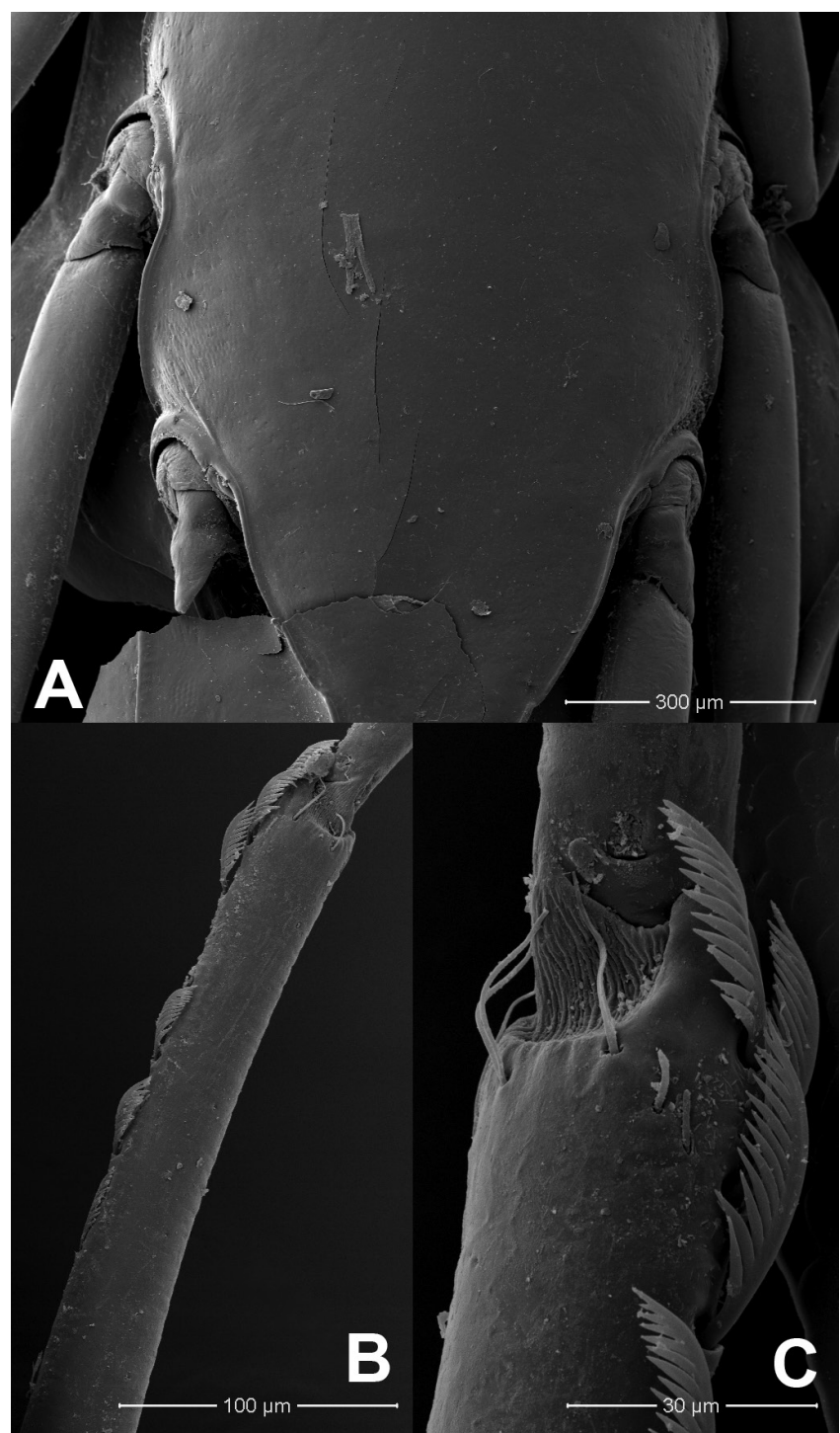

Figure 5. Prosopistoma sinense: A SEMs of sternal plate B ventral margin of fore tibia $\mathbf{C}$ pectinate setae.

Diagnosis. The larvae of $P$. wouterae can be distinguished from those of other congeners by the combination of the following characteristics: (i) apical segment of the maxillary palp shorter than $1 / 2$ the length of segment II, (ii) mesonotum with five dark-brown patches connected by brown narrow stripes, (iii) apex of the ventral margin of the fore-tibiae with eight serrated spines and (iv) posterolateral spine of segments VII and VIII parallel to or bent inwards the body axis (Shi and Tong 2013).

Distribution. Songkhla province (S). 
Remarks. Prosopistoma wouterae was originally described by Lieftinck (1932) from West Java. Parnrong et al. (2002) reported larvae of $P$. wouterae from the Songkhla province. In this study, we sampled in the same stream (Boripat Waterfall) but unfortunately, no specimens were found during our collection. This species seems to have a distribution limited only to the Sunda Islands and southern Thailand. Only four genes (16S, 18S, 28S rDNA, and H3) were sequenced for $P$. wouterae (Ogden and Whiting 2005), and no COI sequences were available for comparison.

\section{Prosopistoma carinatum sp. n.}

http://zoobank.org/E4B47533-39E5-45D6-BFAA-BE6B5E681C7B

Figures 1D, 1F, 6, 7, 8, 9, 10, 12E, 12F, 14

Material examined. Holotype. THAILAND; Holotype, 1 mature larva, Kanchanaburi province, Thong Pha Phum, Ban Pra Chum Mai, 14³5'01.4"N, 98³4'54.3"E, 233 m, 11.IV.2015, B Boonsoong leg. (ZMKU); Paratypes. 1 larva same data as holotype (MZL, GBIFCH00657926); 6 larvae same data as holotype (ZMKU); 1 mature larva, 8 larvae, Kanchanaburi province, Ban Pra Chum Mai, 14³5'01.4"N, 98³4'54.3"E, 233 m, 26.IV.2016, B Boonsoong leg. (ZMKU).

Additional material. THAILAND; 1 larva, Nakhon Si Thammarat province, Lan Sa Ka, Khao Luang water fall, 8²8'08.30"N, 9946'14.20"E, 533 m, 2.VII.2016, B Boonsoong leg. (ZMKU); 1 larva, Narathiwat province, Waeng district, Ai Sae, 547'45.9"N, 10150'5.46"E, 64 m, 21.IV.2018, B Boonsoong leg. (ZMKU).

Distribution. Kanchanaburi province (W), Nakhon Si Thammarat province (S), Narathiwat province $(S)$.

Diagnosis. The larvae of Prosopistoma carinatum sp. n. can be distinguished from those of other species by the combination of the following characteristics (Table 3): (i) carapace with two longitudinal ridges on each side of the midline on its surface (Fig. 1F), (ii) antenna 7-segmented, (iii) carapace with three pale-coloured depressions on each side, (iv) carapace with a very narrow flange width and strong convexity, (v) carapace with a typically brown colouration and a distally irregular (zig-zag) yellow pattern at 0.7 times the length of the carapace, (vi) carapace with circular scale-like structures, (vii) presence of three long serrated bristles at the base of the inner canine and (viii) ventral margin of the fore-tibia with nine pectinate setae.

Description (in alcohol). Body length 1.94-2.43 mm excluding caudal filaments.

Head. Head yellowish with median blackish ocellus between antennae (Fig. 8A), head width approximately 3 times length. Epicranial ecdysial sutures prominent, passing through the anterior margin of the lateral ocelli, and between the compound eyes and the antennal bases and continuing to the lateral margin of the head (Fig. 8B). Antenna 7-segments (Figs 6A, 8B, 8C), longer than the distance from antennal base to anterior margin of head; segment I usually retracts into head capsule; segment III the longest and shorter than combined length of segments IV-VII, antenna segment VII minute (Fig. 8C). Labrum (Fig. 6D) narrow, 3 times wider than long, anterior 

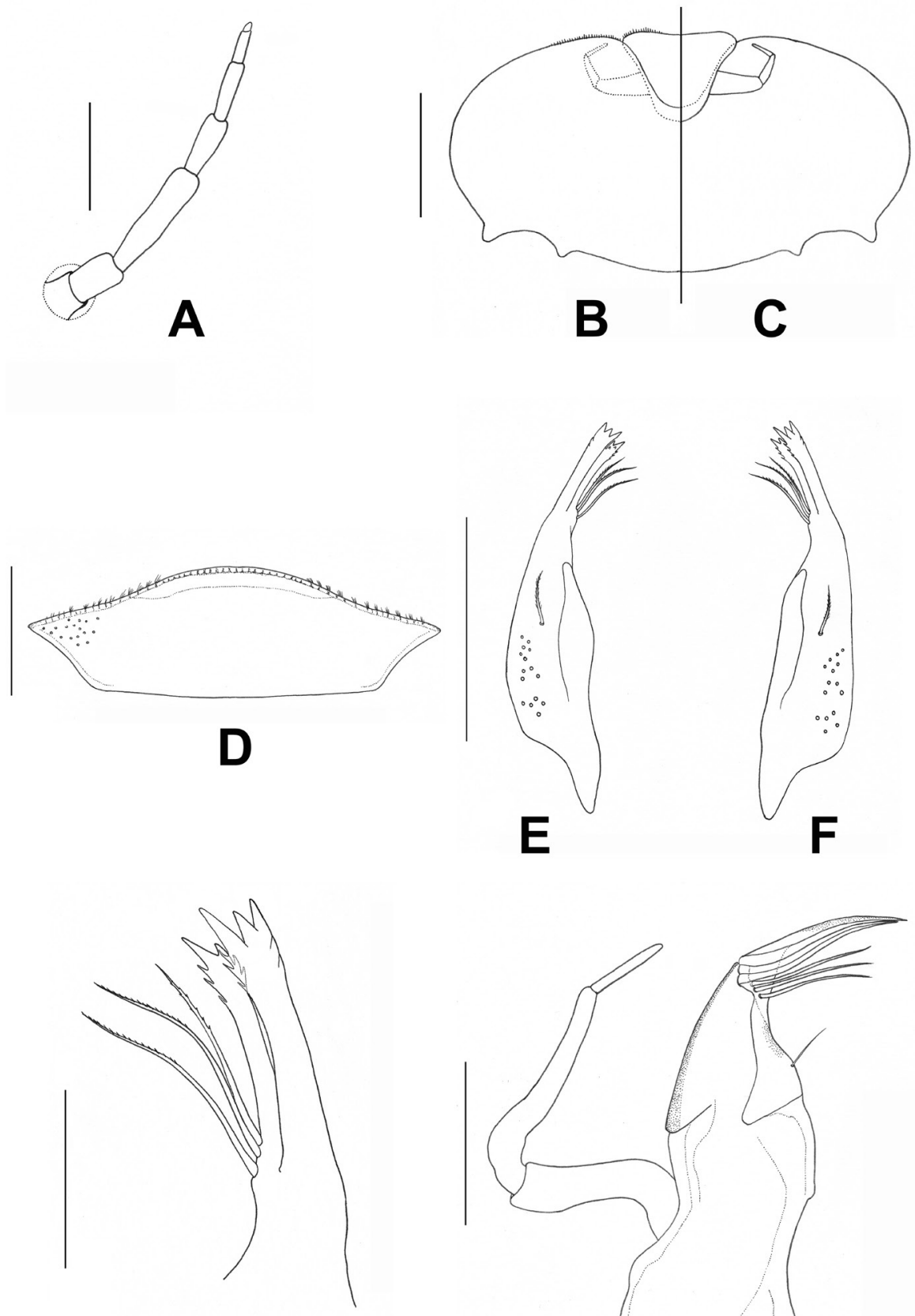

G

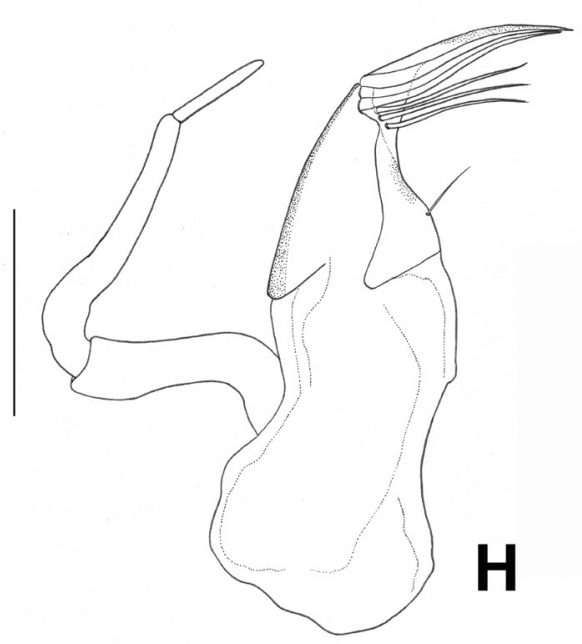

Figure 6. Prosopistoma carinatum sp. n.: A Antenna B-C Labium B ventral view C ventral view D Labrum, dorsal view E-G Mandible E Left mandible (ventral view) F Right mandible (ventral view) G Enlargement of canine of the right mandible, $(\mathbf{H})$. Scale bars: $0.02 \mathrm{~mm}(\mathbf{H}) ; 0.05 \mathrm{~mm}(\mathbf{G}) ; 0.1 \mathrm{~mm}$ $(\mathbf{A}, \mathbf{D}, \mathbf{E}, \mathbf{F}) ; 0.2 \mathrm{~mm}(\mathbf{B}, \mathbf{C})$. 
Table 3. Larval characters of $P$. carinatum sp. n. compared with Thai known species (Soldán and Braasch 1984, Sartori and Gattolliat 2003, Shi and Tong 2013).

\begin{tabular}{|c|c|c|c|c|}
\hline & P. annamense & P. sinense & P. wouterae & P. carinatum sp. $\mathrm{n}$. \\
\hline Distribution & Vietnam, Thailand & China, Thailand & Java, Sumatra, Thailand & Thailand \\
\hline Antennae & 5-segmented & 5-segmented & 6-segmented & 7-segmented \\
\hline $\begin{array}{l}\text { Antenna with segment III to } \\
\text { remaining segments }\end{array}$ & shorter & longer & shorter & shorter \\
\hline $\begin{array}{l}\text { Number of bristles on } \\
\text { mandibles }\end{array}$ & 3 & $4-6$ & 3 & 3 \\
\hline $\begin{array}{l}\text { Number of spines on } \\
\text { foretibiae }\end{array}$ & $4-6$ & $6-8$ & 8 & 9 \\
\hline Carapace flange width & wide & narrow & narrow & very narrow \\
\hline Carapace ridges & no & no & no & 2 ridges on each side \\
\hline Distal end of carapace & incised notch & incised notch & incised notch & protruding notch \\
\hline $\begin{array}{l}\text { Length of inner canine to } \\
\text { outer canine }\end{array}$ & $\begin{array}{l}\text { shorter than outer } \\
\text { canine }\end{array}$ & $\begin{array}{l}\text { shorter than outer } \\
\text { canine }\end{array}$ & subequal & subequal \\
\hline $\begin{array}{l}\text { Ratio length of carapace } \\
\text { (along median suture):width }\end{array}$ & $0.95-1.00(\mathrm{n}=3)$ & $0.96-1.02(\mathrm{n}=3)$ & unknown & $1.07-1.13(\mathrm{n}=3)$ \\
\hline $\begin{array}{l}\text { Convexity: carapace } \\
\text { depth:length }\end{array}$ & $0.39-0.45(\mathrm{n}=3)$ & $0.30-0.49(\mathrm{n}=3)$ & unknown & $0.56-0.58(\mathrm{n}=3)$ \\
\hline
\end{tabular}

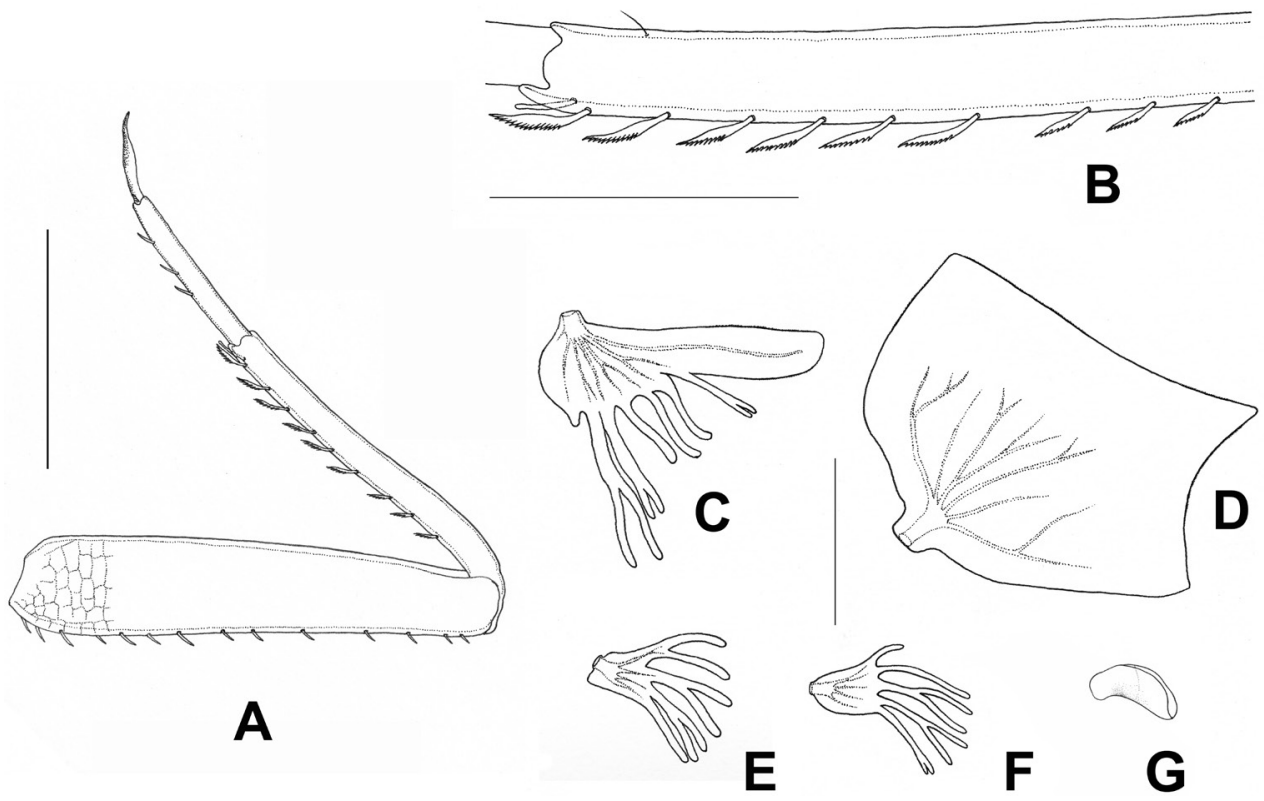

Figure 7. Prosopistoma carinatum sp. n.: (A) Foreleg, (B) Enlargement of part of the fore-tibia to show setation; (C) Gill I; (D) Gill II; (E) Gill IV; (F) Gill V; (G) Gill VI. Scale bars $0.1 \mathrm{~mm}(\mathbf{B}) ; 0.2 \mathrm{~mm}(\mathbf{A})$; $1 \mathrm{~mm}(\mathbf{C}-\mathbf{F})$. 


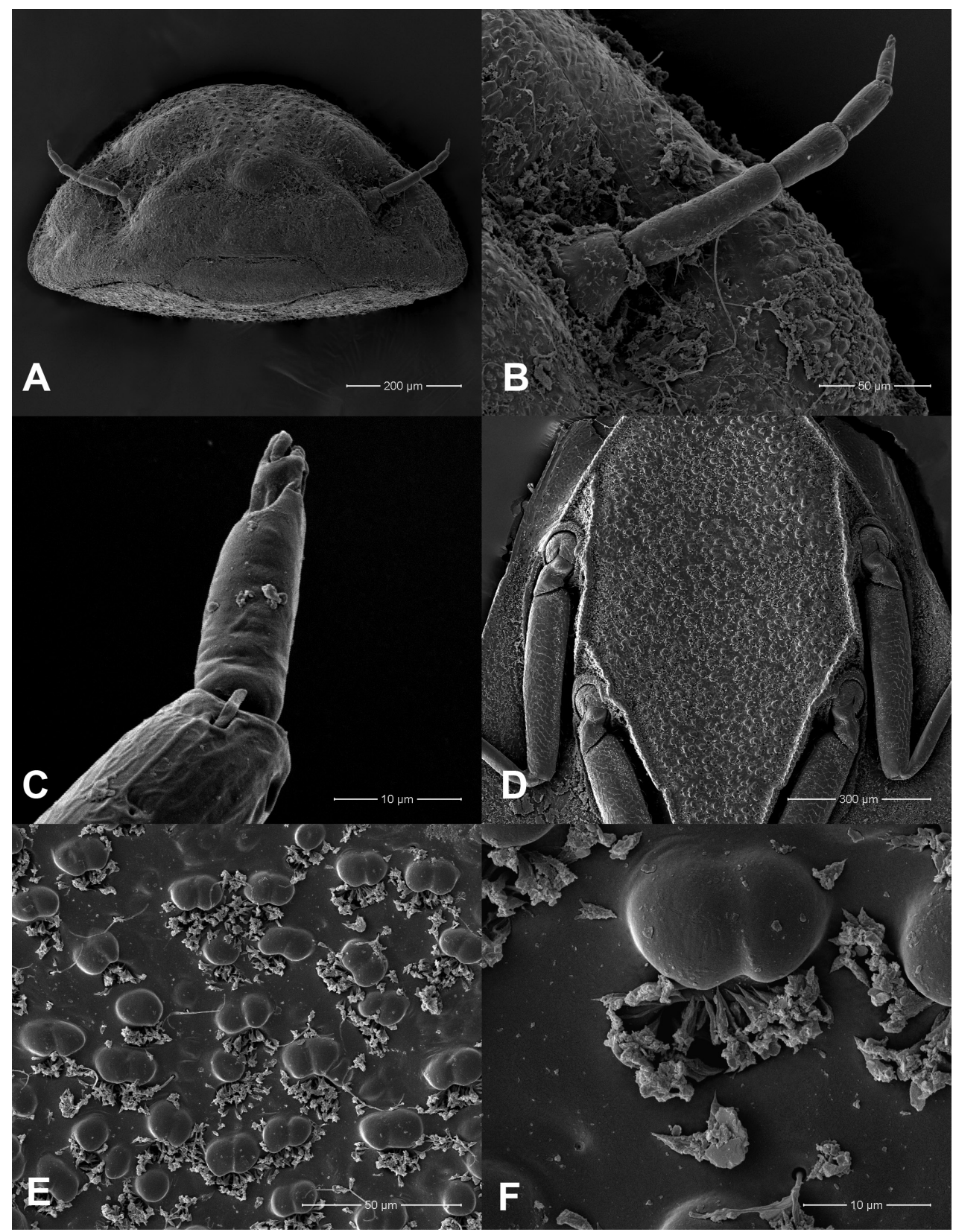

Figure 8. Prosopistoma carinatum sp. n.: A SEMs of head, frontal view $\mathbf{B}$ antenna, frontal view $\mathbf{C}$ tip of antenna $\mathbf{D}$ sternal plate and legs $\mathbf{E}$ closer view of surface of sternal plate $\mathbf{F}$ closer view showing details of scale-like structures. 


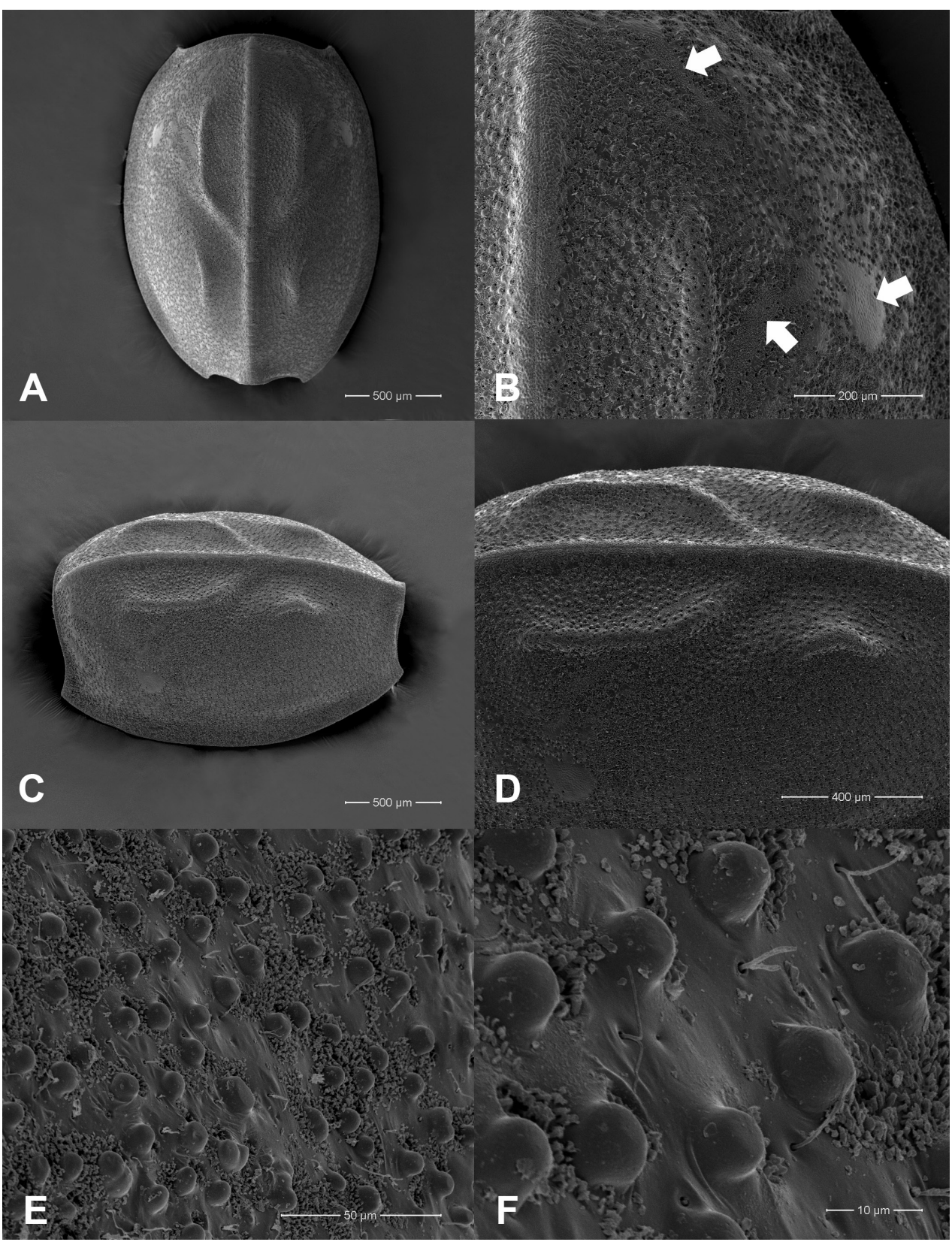

Figure 9. Prosopistoma carinatum sp. n.: A SEMs of notal shield, dorsal view B pale-coloured areas on carapace (arrows) C dorsolateral view of carapace D ridged longitudinal lines, dorsolateral view E scalelike structures $\mathbf{F}$ closer view showing details of scale-like structures. 


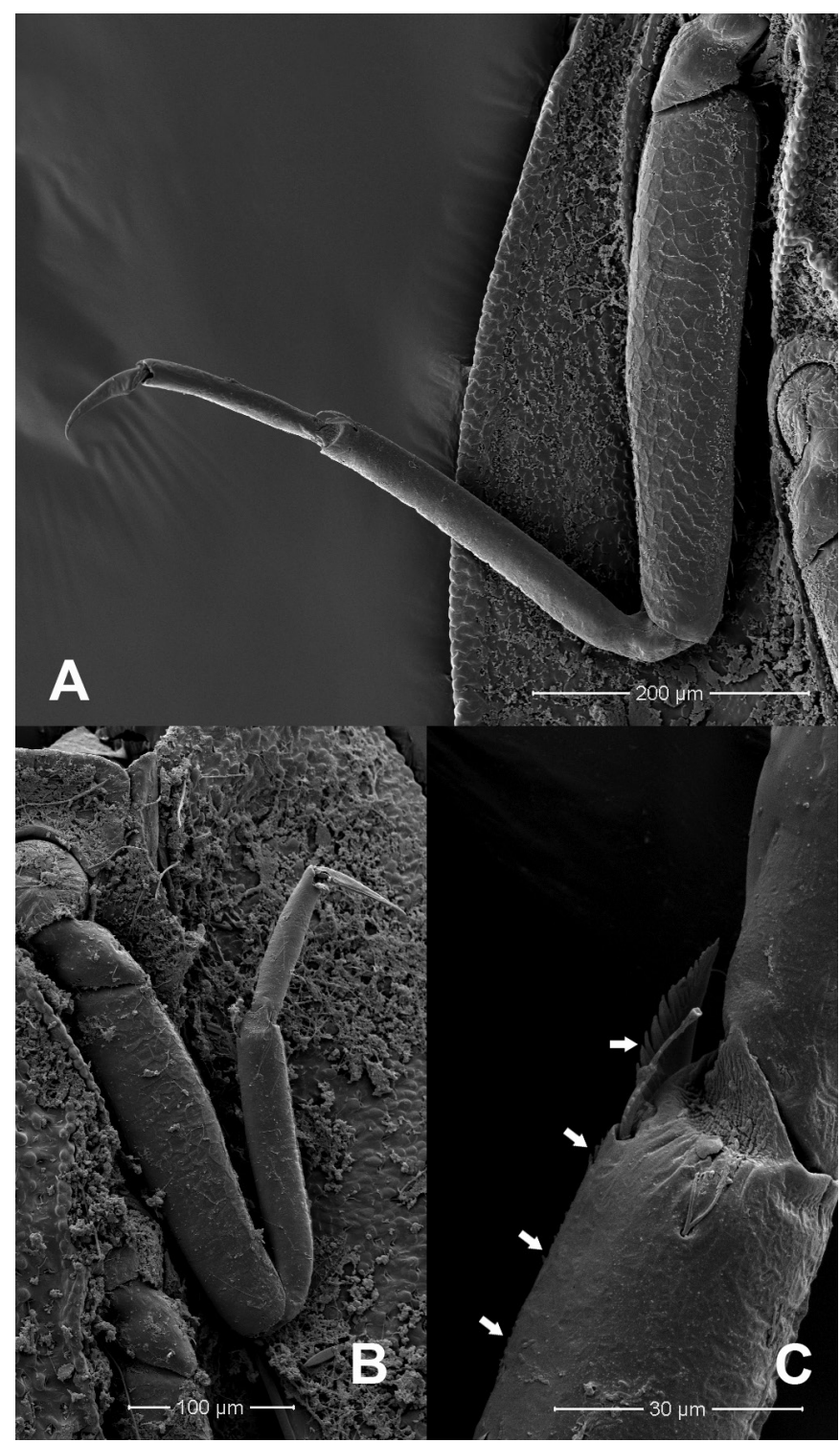

Figure 10. Prosopistoma carinatum sp. n.: A SEMs of middle leg showing scale-like pattern on femur, ventral view $\mathbf{B}$ ventral margin of fore tibia $\mathbf{C}$ pectinate setae (arrows).

margin fringed with dense fine setae. Left and right mandibles similar (Fig. 6E, 6F). Outer canine of mandibles subequal and broader than inner canine, with three apical teeth, a smaller outer tooth and a larger inner tooth with a serrated margin near the apex and three small spines; inner canine with two apical teeth, including a larger inner one with a serrated inner margin near the apex with three spines. Three long serrated 
bristles arising from the base of the inner canine (Fig. 6G). A single stout feathered seta lateromedially on each mandible (Fig. 6E, 6F). Maxillae (Fig. 6H) crowned by a rigid canine and three subequal moveable dentisetae; three long-feathered stout bristles arising near the base of the apical canine and dentisetae on the galea-lacinia. A single unserrated bristle arising approximately $2 / 3$ of the way down the sclerotised section of the galea-lacinia. Maxillary palpi 3-segmented, segment II the longest, length ratio of maxillary palp segments from basal one to apical: 1.9:2.2:1(Fig. 6H).

Carapace. Carapace general colouration dark brown, distally with an irregular (zig-zag) yellow pattern at 0.7 times the length of the carapace (Fig. 1D). Two longitudinal ridges on the anterior surface region, and two short ridges on the pale surface area (Figs 1D, 1F, 9A, 9C, 9D). Carapace with one pale-coloured circular depression on lateral side of the anterior region (Figs 1F, 9B) and two pale-coloured striped depressions at the midline. Carapace flange width very narrow. Cuticle of carapace coarsely pitted and interspersed with scale-like structures (Fig. 9E, F). Distal margin of the carapace protruding slightly over the exhalent notch (Figs 1D, 9A). In lateral view, carapace strongly convex, with a convexity (ratio of maximum carapace height to length along the posterior margin of the carapace) range 0.56-0.58. Sternum pitted, with coarse scale-like structures within the triangular sternal plate (Fig. 8D, F).

Legs. Dorsal margin of fore femur with 14 short simple setae (Fig. 7A); ventral margin of fore tibia with nine pectinate setae (Figs 7B, 10C). Anterior and posterior surface of femur covered with scale-like pattern (Figs 7A, 10A). Tarsal claws of all three pairs of legs sharp and without denticles.

Abdomen. Abdominal gills (Fig. 7C-G). Gill I with lamellate upper portion, margin serrated, lower portion divided into multiple filaments (Fig. 7C). Gill II expanded to form broad leaf-like lamella (Fig. 7D). Gills III-V with multiple branching filaments (Fig. 7E, F). Gill VI tiny, unbranched (Fig. 7G). Posterolateral projections of abdominal segments VII-IX broad, apex pointed. Caudal filaments small, retractile, short, feathered.

Subimago and Imago. Unknown.

Etymology. The name carinatum (Latin for carinate or keeled), refers to the prominent keels or ridge-like mesonotal convexity of the species.

\section{Mitochondrial COI sequence analysis}

The partial sequences of the mitochondrial COI gene $(658 \mathrm{bp})$ of three species found in Thailand were analysed to investigate species delineation. Ten specimens of Prosopistoma were examined. In this study, we used Baetisca laurentina from GenBank (HM902945 and KR144660) as the outgroup since Baetiscidae is the sister family of Prosopistomatidae (Ogden et al. 2009). The consensus phylogenetic tree of ML analysis is shown in Figure 11. The tree clearly showed a monophyletic clade for the new species ( $P$. carinatum sp. n.). Clade 2 includes $P$. annamense and $P$. sinense. The interspecific genetic distance ranged from 31 to $35 \%$ among the investigated species (Table 2). 


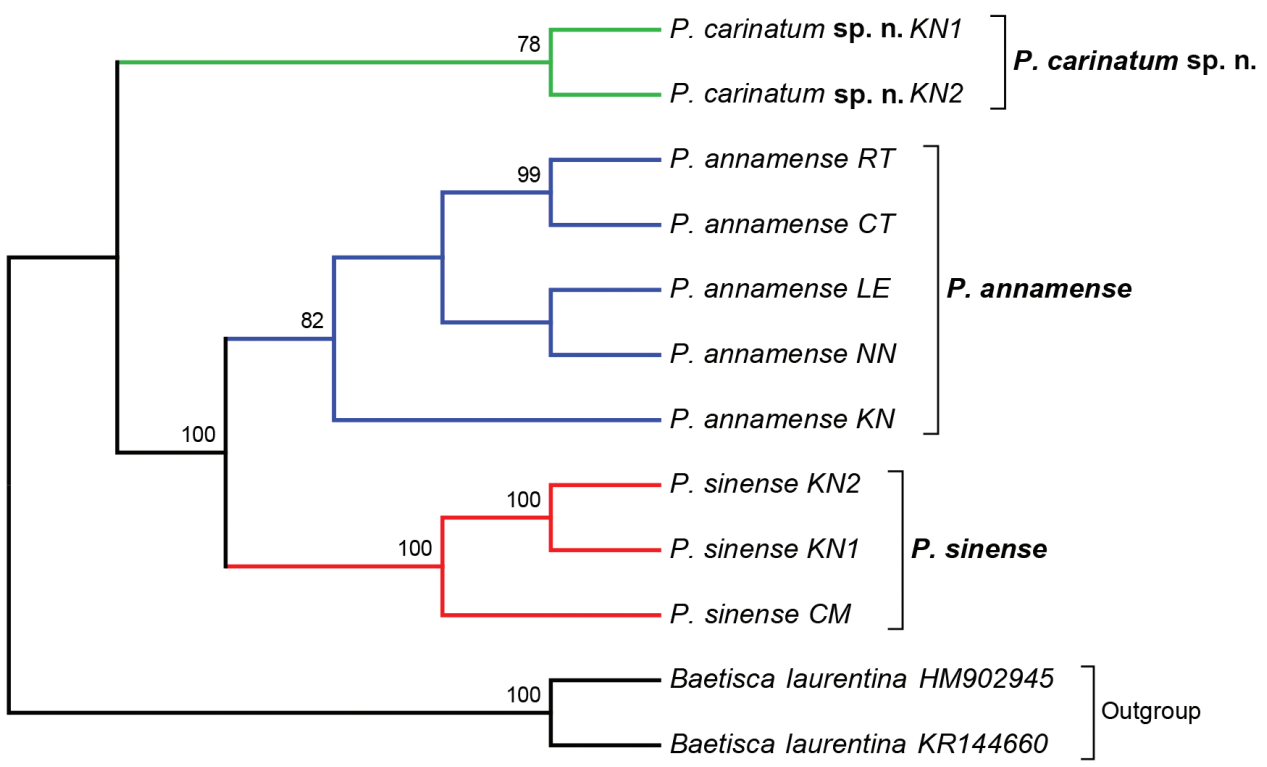

Figure I I. Consensus phylogenetic tree based on the maximum likelihood (ML) analysis of three Thai Prosopistoma species (the best model: $\mathrm{T} 92+\mathrm{G}$, parameter $=0.2619$ ). The bootstrap consensus tree inferred from 1,000 replicates. Values above the branches are ML bootstrap values (> 70\%). Baetisca laurentina from GenBank was used as the outgroup. There were a total of 658 positions in the final dataset. Abbreviations are the same as those found in Table 1.

\section{Discussion}

The molecular analysis revealed that Prosopistoma carinatum sp. n. is clearly separated from the other species. The molecular analysis suggests the morphological distinction between the three species. Morphologically, the new species differs from the two previously known species (P. annamense and $P$. sinense) by (i) longitudinal line ridges on the carapace, (ii) a strongly convex carapace, (iii) the sternal plate, (iv) the scale-like structures on the carapace, (v) 7-segmented antennae and (vi) nine pectinate setae on the ventral margin of the fore-tibiae. The larvae of $P$. annamense and $P$. sinense were placed in the same clade, and they share the characteristics of 5-segmented antenna and a smooth carapace. Moreover, the sternal plate of $P$. annamense and $P$. sinense has smooth surface (Figs 3A, 5A), while in P. carinatum sp. n. it bears distinctive scale-like structures (Fig. 8D-F). SEM examination on the carapace of the new species reveals a covering of circular scale-like structures scattered over the surface (Fig. 9E, 9F). The cuticle patterns of carapace of $P$. annamense is quite similar to $P$. sinense (Figs 2A-D, $4 \mathrm{~A}-\mathrm{D})$, which are smoother than in the new species.

A comparison of the larvae of all Thai species is shown in Table 2. The irregular (zig-zag) pattern which occur on the carapace of $P$. carinatum sp. n. can also be found in $P$. annamense and $P$. leftincki. The comparison between the new species and other known Oriental species indicates close morphological similarity between $P$. carinatum 
sp. n. and P. someshwarensis (from India) in terms of the presence of a longitudinal line that looks like a ridge (Roopa et al. 2017). However, the new species can be easily distinguished by its two distinct longitudinal ridges.

\section{Ecology}

The beetle-like mayfly larvae Prosopistoma inhabit shallow water under small stones in streams with a moderate to rapid current (Soldán and Braasch 1984, Sartori and Gattolliat 2003, Shi and Tong 2013). It is well documented that Prosopistomatidae are sensitive to pollution (Barber-James 2010). In this study, the habitats of the larvae were generally located in undisturbed upstream sites (forest streams), except $P$. annamense, which could be found in both disturbed and undisturbed sites. In addition, the larvae of $P$. annamense were also found in large rivers, including in the large urban river Xiangjiang in China (Yam 2015). In general, the larvae of Prosopistoma are rarely collected. In this study, most of the larvae were found from February through April in streams, with the exception of the southern region, in which they were found in July. Prosopistoma

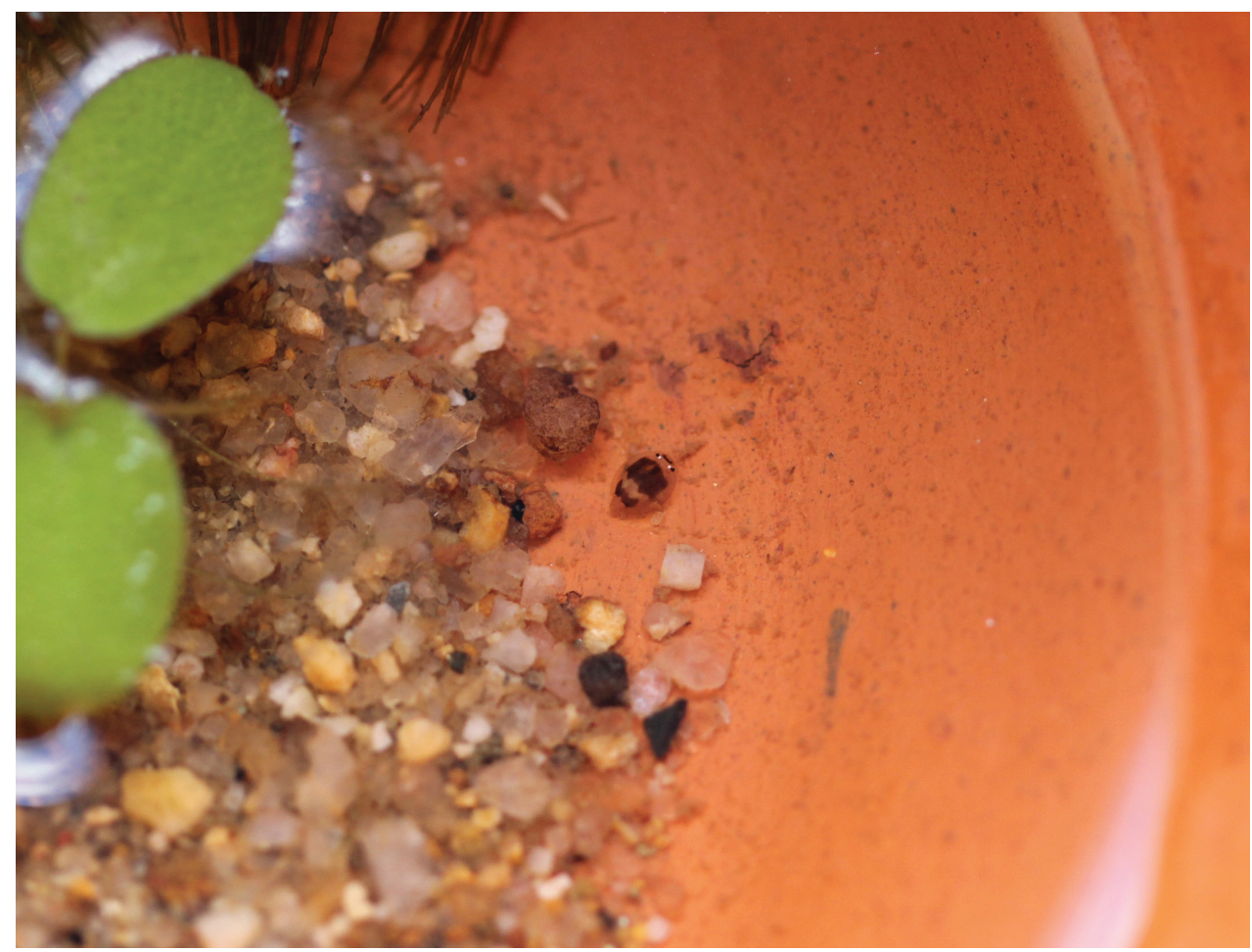

Figure 13. Rearing chamber of Prosopistoma annamense larva. 

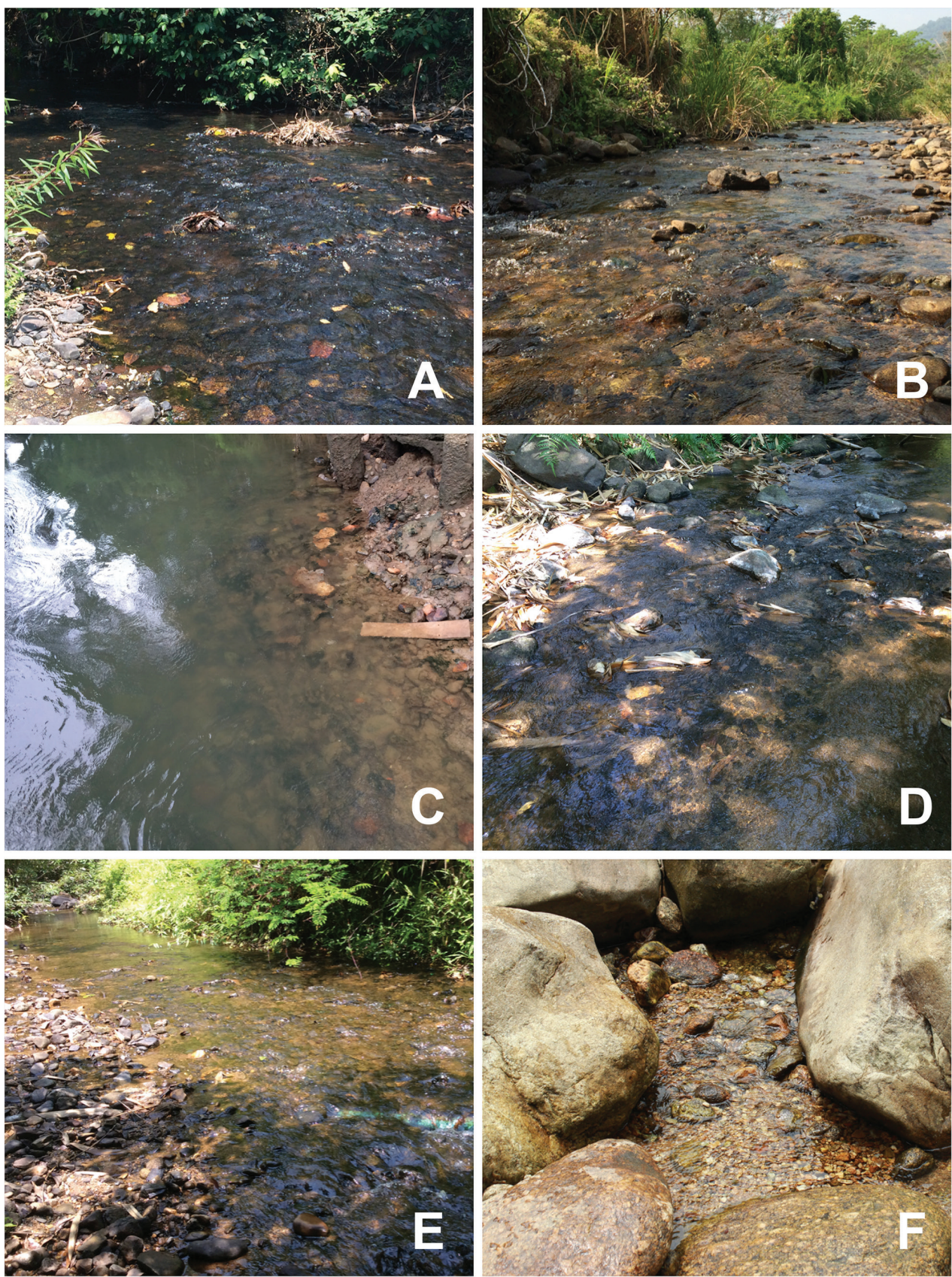

Figure 12. Habitats of Prosopistoma larvae: A-C P. annamense $\mathbf{A}=$ Loei province $\mathbf{B}=$ Nakhon Nayok province $\mathbf{C}$ = Kanchanaburi province (Khwae Noi River) D P. sinense (Kanchanaburi province) E-F $P$. car inatum sp. n. $\mathbf{E}=$ Kanchanaburi province $\mathbf{F}=$ Nakhon Si (Thammarat province). 
annamense larvae were found in October in large rivers. The ecological aspects of Thai Prosopistoma, such as microhabitat, feeding, life history and season of larval maturity, should be explored in more detail. In this study, the larvae $P$. annamense were reared in an earthenware pot with aquatic plants without an extra air supply (Fig. 13). Under these conditions, the larvae can grow to maturity and survive for approximately one month. However, the fully-grown larvae did not moult to the subimaginal stage.

In Thailand, the Isthmus of the Kra region is a widely recognised as a biogeographic boundary (Hughes et al. 2003, de Bruyn et al. 2005, Jantarit et al. 2013). The distribution of the Prosopistomatidae in Thailand is shown in Figure 14. Prosopistoma sinense, which belongs to the 'P. variegatum' clade (Barber-James 2009), is distributed only in the north and west of Thailand, whereas $P$. annamense is widely spread through northeast, central, and west Thailand. However, neither $P$. annamense nor $P$. sinense were found on the other side of the isthmus. The distribution of $P$. carinatum sp. $\mathrm{n}$. seems to overlap the isthmus region, and this species apparently falls into the 'African' clade. Barber-James (2009) examined the distribution of $P$. wouterae and suggested

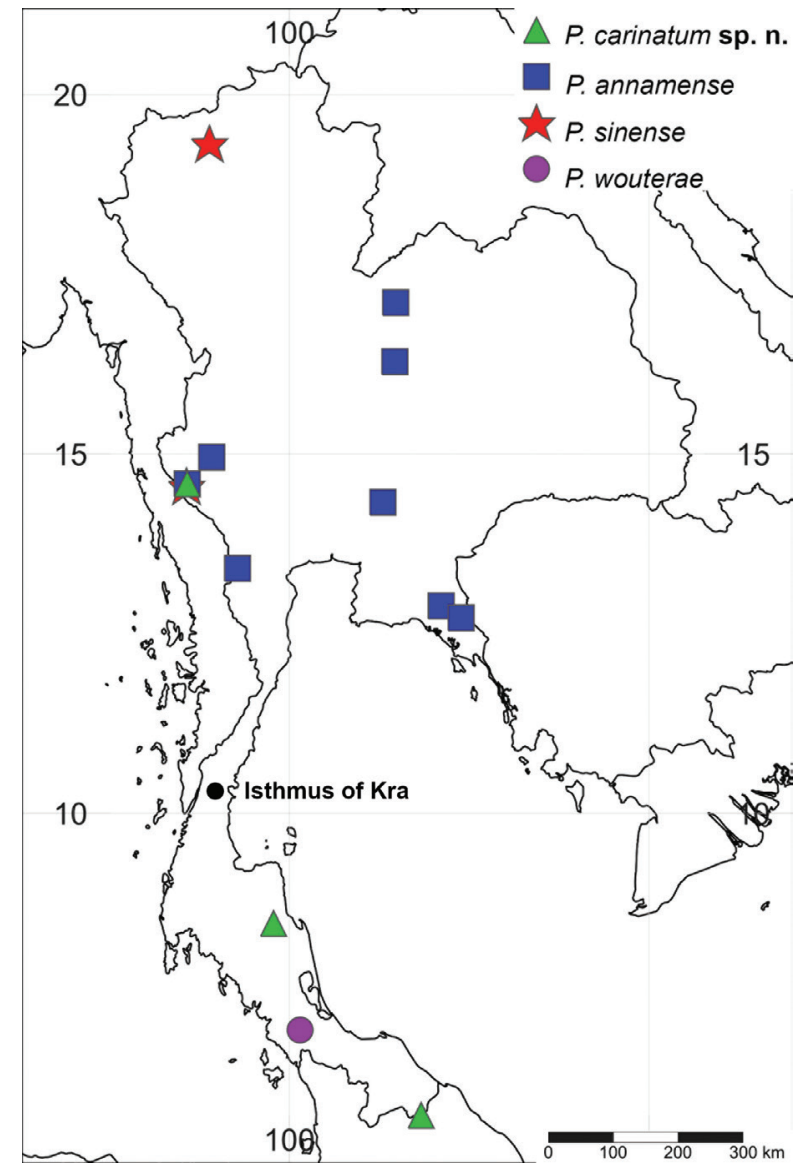

Figure 14. Distribution map of the four known Thai Prosopistoma species. 
that there was a more recent dispersal from the Sunda Islands of this species after the sea level dropped. Prosopistoma wouterae seems to be restricted to the south of the Isthmus of Kra.

\section{Acknowledgements}

This research has been supported by the Centre of Excellence on Biodiversity (BDC) Office of Higher Education Commission (BDC-PG2-161004). We are most grateful to our colleagues for assistance during field trips. The authors would like thank the subject editor, Dr Helen Barber-James, and Dr Frederico Salles for their comments on the manuscript. We would also like to thank the Department of Zoology and the Faculty of Science at Kasetsart University in Bangkok for their assistance and use of their facilities.

\section{References}

Balachandran C, Anbalagan S, Kannan M, Dinakaran S, Krishnan M (2016) A new species of Prosopistoma Latreille, 1833 (Ephemeroptera: Prosopistomatidae) from South India. Zootaxa 4178(2): 289-294. https://doi.org/10.11646/zootaxa.4178.2.7

Barber-James HM (2009) A preliminary phylogeny of Prosopistomatidae (Ephemeroptera) based on morphological characters of the larvae, and an assessment of their distribution. Aquatic Insects 31: 149-166. https://doi.org/10.1080/01650420903020502

Barber-James HM (2010) Two new species of Prosopistomatidae (Ephemeroptera) from South Africa and Swaziland. African Entomology 18(1): 147-165. https://doi. org/10.4001/003.018.0112

Barber-James HM, Gattolliat JL, Sartori M, Hubbard MD (2008) Global diversity of mayflies (Ephemeroptera, Insecta) in freshwater. Hydrobiologia 595: 339-350. https://doi. org/10.1007/s10750-007-9028-y

De Bruyn M, Nugroho E, Hossain MM, Wilson JC, Mather PB (2005) Phylogeographic evidence for the existence of an ancient biogeographic barrier: the Isthmus of Kra Seaway. Heredity 94(3): 370-378. https://doi.org/10.1038/sj.hdy.6800613

Folmer O, Black M, Hoeh W, Lutz R, Vrijenhoek R (1994) DNA primers for amplification of mitochondrial cytochrome c oxidase subunit I from diverse metazoan invertebrates. Molecular Marine Biology and Biotechnology 3(5): 294-299.

Gattolliat JC, Cavallo E, Vuataz L, Sartori M (2015) DNA barcoding of Corsican mayflies (Ephemeroptera) with implications on biogeography, systematics and biodiversity. Arthropod Systematics \& Phylogeny 73(1): 3-18. http://www.senckenberg.de/files/content/forschung/publikationen/arthropodsystematics/asp_73_1/01_asp_73_1_gattolliat_3-18.pdf

Hughes JB, Round PD, Woodruff DS (2003) The Indochinese-Sundaic faunal transition at the Isthmus of Kra: an analysis of resident forest bird species distributions. Journal of Biogeography 30: 569-580. https://doi.org/10.1046/j.1365-2699.2003.00847.x 
Jantarit S, Satasook C, Deharveng L (2013) The genus Cyphoderopsis Carpenter (Collembola: Paronellidae) in Thailand and a faunal transition at the Isthmus of Kra in Troglopedetinae. Zootaxa 3721(1): 49-70. https://doi.org/10.11646/zootaxa.3721.1.2

Kumar S, Stecher G, Tamura K (2016) MEGA7: Molecular Evolutionary Genetics Analysis version 7.0 for bigger datasets. Molecular Biology and Evolution 33: 1870-1874. https:// doi.org/10.1093/molbev/msw054

Lafon J (1952) Note sur Prosopistoma foliaceum Fourc. (Ephémoroptère). Bulletin de la Société Zoologique de France 77(5-6): 425-436.

Latreille M (1833) Description d'un nouveau genre de crustacés. Annales du Museum National, Paris 2: 23-34.

Lieftinck MA (1932) A new species of Prosopistoma from the Malay Archipelago (Ephemeroptera). Tijdschrift voor Entomologie (supplement) 75: 44-55.

Ogden TH, Whiting MF (2005) Phylogeny of Ephemeroptera (mayflies) based on molecular evidence. Molecular Phylogenetics and Evolution 37: 625-643. https://doi.org/10.1016/j. ympev.2005.08.008

Peters WL (1967) New species of Prosopistoma from the Oriental Region (Prosopistomatidae: Ephemeroptera). Tijdschrift voor Entomologie 110: 207-222.

Sartori M, Gattolliat JL (2003) First record and new species of the genus Prosopistoma Latreille, 1833 (Ephemeroptera, Prosopistomatidae) from Borneo (East Kalimantan, Indonesia). Mitteilungen der Schweizerischen Entomologischen Gesellschaft 76: 301-305.

Parnrong S, Buathong M, Sites RW (2002) New records of Behningiidae, Potamanthidae, and Prosopistomatidae (Ephemeroptera) from Thailand. ScienceAsia 28: 407-409.

Peters WL (1967) New species of Prosopistoma from the Oriental Region (Prosopistomatoidea: Ephemeroptera). Tijdschrift voor Entomologie 110: 207-222.

Roopa SR, Selvakumar C, Subramanian KA, Sivaramakrishnan KG (2017) A new species of Prosopistoma Latreille, 1833 and redescription of P. indicum Peters, 1967 (Ephemeroptera: Prosopistomatidae) from the Western Ghats, India. Zootaxa 4242(3): 591-599. https:// doi.org/10.11646/zootaxa.4242.3.10

Shi W, Tong X (2013) A new species of Prosopistoma (Ephemeroptera: Prosopistomatidae) from China with a key to Oriental species. Zootaxa 3718: 89-096. https://doi.org/10.11646/ zootaxa.3718.1.8

Soldán T, Braasch D (1984) Two new species of the genus Prosopistoma (Ephemeroptera: Prosopistomatidae) from Vietnam. Acta Entomologica Bohemoslovaca 81: 370-376.

Tong XL, Dudgeon D (2000) A new species of Prosopistoma from China (Ephemeroptera: Prosopistomatidae). Aquatic Insects 22: 122-128. https://doi.org/10.1076/01650424(200004)22:2;1-p;ft122

Tungpairojwong N, Boonsoong B (2011) New records of Isonychia formosana, Prosopistoma annamense and Prosopistoma sinense (Ephemeroptera) from Thailand. Ecological Research 41(2): 66-69. https://doi.org/10.1111/j.1748-5967.2011.00317.x

Yam RSW (2015) First record of the genus Prosopistoma Latreille, 1833 (Ephemeroptera, Prosopistomatidae) in Taiwan. ZooKeys 473: 147-156. https://doi.org/10.3897/zookeys.473.8787

Zhou CF, Zheng LY (2004) The genus Prosopistoma from China, with descriptions of two new species (Ephemeroptera: Prosopistomatidae). Aquatic Insects 26: 3-8. https://doi. org/10.1076/aqin.26.1.3.35375 